\title{
Middle Insomnia
}

National Cancer Institute

\section{Source}

National Cancer Institute. Middle Insomnia. NCI Thesaurus. Code C35582.

Difficulty maintaining sleep. 